\title{
Non-state Actors, Terrorism and the New Global Reality
}

\section{Aituaje Irene Pogoson}

Department of Political Science

University of Ibadan, Ibadan, Nigeria

DOI:10.36108/NJSA/8102/61(0190)

We have seen their kind before. They are the heirs of all the murderous ideologies of the 20th century. By sacrificing human life to serve their radical visions-by abandoning every value except the will to power-they follow in the path of fascism, and Nazism, and totalitarianism. And they will follow that path all the way, to where it ends: in history's unmarked grave of discarded lies.

-President George W. Bush

Address to a Joint Session of Congress and the American People September 20, 2001

\begin{abstract}
The reality that terrorists are increasingly enjoying a force-multiplier effect in both national and international realms is the preoccupation of this paper. The traditional thinking about international relations premised on the state as the primary actor in international politics is being greatly challenged as opposition to the supremacy of the state in international system by violent non state actors have become more rampant. Global events demonstrate how the influence of non-state actors and individuals is growing in world politics, assisted by an environment in which the flow of both information and disinformation enables the adoption of narratives that are not particularly based on sound facts and objective knowledge. The implication is that those involved in national and international security in the 21 st century will need to formulate and re-strategize more effective, less military propelled ways and means that address the individual's capacity to distinguish between rational and irrational in order to positively influence the forces that trigger the rise of such extremism in the first place. Until that is achieved, the threats from violent non state actors will continue to challenge some states as the terrorist groups align with others to create a convoluted and perplexing set of geopolitical and organizational networks that will prove difficult to unravel.
\end{abstract}

Keywords: States, violent non state actors, terrorist networks, global realities

\section{Introduction}

The second half of the 20th century witnessed an extraordinary growth in the number of international actors and dramatic changes in the scope of international connectivity. Nation-states are no longer the primary actors on the globe's stage as the growth of non-state actors has meant more diversity in potential players and partners. Globalization (and in favour of regional and 
global governance) is strengthening the role of non-state actors in world affairs at the same time that terrorists are deploying modern technology to plan and operate worldwide in an unprecedented manner. This is because advancement in information technology and communications has come with improved ability for terror-groups to coordinate their activities among dispersed cells while remaining elusive. Kegley and Wittkopf (1995: 2) maintain that "as the world grown smaller, the mutual dependence of nation-states and other transnational political actors on one another has grown". By establishing links with other like-minded organizations around the globe, the reality is that today's terrorists are increasingly enjoying a force-multiplier effect (CIA, 2003: 10). The traditional thinking about international relations premised on the state as the primary actor is being greatly challenged with recent global events demonstrating the growing influence of non-state actors and individuals in world politics (Mulaj, 2009; Arasli, 2011; Ezrow, 2017). This occurrence has been assisted by an environment in which the flow of both information and disinformation enables the adoption of narratives that are not particularly based on sound facts and objective knowledge. The environment has changed the playing field for states and opened up the space for anyone who can create a competing narrative.

Though states and intergovernmental institutions remain central to international politics, the capacity of non-state actors to progressively shape outcomes in global politics is attracting global empirical attention. For example, Ataman has observed that "The proliferation of non-state actors has recently led some observers of international relations to conclude that states are declining in importance and that non-state actors are gaining status and influence" (Ataman, 2003: 43).

Currently, international politics is shaped, "negotiated and implemented by a myriad of actors at multiple levels and in ever more complex ways" (EEA, 2011: 4). Besides, world politics, according to Cerny (2010) is typified by a collection of actors and the emergence of new forms of global governance. These non-state actors are many and are divided into two categories: international intergovernmental organizations (IGOs) and transnational or international non-governmental organizations (NGOs) (Miller, 1994; Josselin \& Wallace, 2001; Ertürk, 2015). Specifically, they range from Intergovernmental Organizations (IGOs), Transnational Corporations (TNCs), Non-Governmental Organizations (NGO), Multinational Corporations (MNCs) and private security firms, and Violent Non-State Actors (VNSAs) such as international criminal groups and terrorist networks. Intergovernmental Organizations (IGOs) are created by nation-states and are officially documented by government agencies. All the other types are established by groups of individuals, persons and other societal forces. This group are global in nature and they are not legally bonds with states. The various types of non- 
state actors operate in different ways and manners in influencing international relations.

The non-state actors have emerged in international relations as important actors. Similarly, they are establishing themselves both at the domestic as well as international level and they influence international security to a greater extent. The degree and nature of the influence may however vary from one non state actor to the other; and additionally, their influence could be positive or negative or at a large or a small scale (Weiss, Seyle \& Coolidge, 2013). Evidently, the evolution of various non-state actors has altered the dynamics and consequences of global politics as new actors in diverse sectors and spheres have begun to engage more prominently in international and multiactor and multilevel networks (EEA, 2011: 4). Ataman, citing Miller (1994), maintained that, "The growth of so many kinds of non-state actors challenges and even weakens the "state-centric" concept of international politics and replaces it with a "transnational" system in which relationships are more complex. These organizations changed the international environment" (Ataman, 2003: 42). The growth and diversity of non-state actors poses new challenges to the international realm.

In contemporary times, political violence inflicted by non-state actors have become prevalent in international relations. Terrorist groups employ increasingly confrontational activities, and in some cases, these activities have been the stimulus for interstate and intrastate conflicts. The presence of violent non-state actors: terrorists, paramilitaries, insurgents, or other types, have throughout history, been a part of international conflicts (Williams, 2008).

An evaluation of the emerging trend in international relations suggests that violent non-state actors have become a powerful challenge to nation-states as state control of the use of force is increasingly being reduced and no state is free of the activities of violent, non-state actors (Gentry, 2015. The realization that violent non-state actors have the potential to play a unique role in international politics suggests that they are most clearly challenging states' authority. These group of actors have taken different forms in different parts of the world. "These forms include tribal and ethnic groups, warlords, drugtrafficking organizations, youth gangs, terrorists, militias, insurgents and transnational criminal organizations" (Williams, 2008: 4).

\section{Theorizing Terrorist Groups as Non-State Actors}

One basic explanation for how terrorist groups as non -state actors behave is the instrumental approach. The instrumental approach's scope of analysis is political. It is based on the assumption that acts of terrorism is a deliberate choice by a political actor and the actions of terrorist organizations is to achieve political ends. "The instrumental approach to terrorism is one of the most developed approaches to the subject in the discipline of political science" (Özdamar, 2008: 93). It is substantially influenced by conflict studies, so its range is quite broad as it applies to all manner of conflict regardless of the identity of the actors (Crenshaw, 1987). As Crenshaw (1987) suggests, when 
juxtaposed against logical rules, the intents of the actors can be easily inferred from their behaviour. This approach according to Crenshaw (1995) assumes that violence is an intentional act for a terrorist organization. Therefore, violence is not the ends instead; terrorism is a tool for these actors to achieve political ends.

The instrumental approach assumes that individuals and the organizations they establish are created in response to perceived injustices or problems. Terrorism is understood to be a response to external impetuses, especially government actions and policies and the quest to change other actors' decisions, actions, and policies by using force. According to Crenshaw (1987), terrorism is an extreme form of political behaviour and the actions of terrorist organizations is to achieve collective values through radical changes in political and social conditions.

This approach suggests that as non-state organizations, terrorist groups undertake cost and benefit analysis in deciding their course of actions and the probability of the success in their actions. Instrumental theorists (Crenshaw, 1987; Long, 1990) imply that attaining the political ends are indeed important, therefore, the survival of the terrorist organization even when the ultimate aims cannot be achieved, could be explained by the achievement of intermediate aims. As noted by Crenshaw (1987), terrorism survives because the terrorist organizations achieve their tactical aims such as publicity and recognition. This explanation is plausible in light of some political changes that terrorist organizations were able to achieve, even when they fail to reach their ultimate political ends. The instrumental approach further suggests that factions within the terrorist groups emerge from disagreements about the political ends, ideological positions, or failed attempts to achieve these aims (Crenshaw, 1987; Long 1990). For example, the factions in the ISIS, Boko Haram among others are the illustrations of how terrorist groups split after serious concerns over achieving political ends in the group. Despite the instrumental approach's weakness of failing to adequately explain how the preferences of the actors are determined, it provides a firm base to develop comprehensive theories of terrorism.

\section{Challenges of Terrorism in International Politics}

A major shift taking place in contemporary global politics is the shift in polity power from the prominence of the state to the rising prominence of non-state actors (Ersel and Aydinli, 2013). One factor that cannot be ignored in the developing international power structure is the role of terrorist organizations. We live in an age of international terrorism with its increasing scope and violence. Terrorism has been a dark feature of human behaviour since the beginning of documented history as terrorist organizations have increasingly endangered the security, infrastructure, and citizens of nations and communities globally. "Great leaders have been assassinated, groups and 
individuals have committed acts of credible violence, and entire cities and nations have been put to the sword- all in the name of defending a greater good" (Martin, 2003: 2). Terrorist organizations differ in structure, operational reach, motivations, recruitment and capabilities. They also vary in size-from large terrorist organizations, small cells and individual terrorists to sole actors. "The nature and type of terrorism has become more varied and complex and terrorist organizations even more evasive and difficult to understand" (Pogoson, 2013: 27).

Terrorism is, in the broadest sense, the use of intentionally indiscriminate violence as a means to create terror or fear, in order to achieve a political, religious or ideological aim. It is used in this regard primarily to refer to violence against peacetime targets or in war against non-combatants (Pogoson, 2013; Hoffman, 2006; Dedeoglu, 2003). The Global Terrorism Database defines terrorism as "the threatened or actual use of illegal force and violence by a non-state actor to attain a political, economic, religious, or social goal through fear, coercion, or intimidation" (Global Terrorism Database, 2017). The central feature of terrorism is that it is a form of political violence that aims to achieve its objectives by creating a climate of fear and apprehension (Heywood, 2011; Goodin, 2006). Clearly, the definition of terrorism can be an exercise in semantics and context, driven by one's perspective and worldview. Part of "the problem is that there exists no precise or widely accepted definition of terrorism" (Riley and Hoffman, 1995: 2). Irrespective of the definition however, terrorism has always challenged the stability of societies and the peace of mind of everyday people.

Despite the differences among terrorist organizations, terrorism continues to adjust to the challenges of emerging forms of conflict, and developments in technology and society (Jackson, Smyth and Jarvis, 2011). With the development of new capabilities of attack and improvement in the effectiveness of their existing methods, terrorism has established increasing abilities to adjust to counter-terrorism measures and political failure. Additionally, terrorist groups have demonstrated substantial progress in shaking off a subordinate role in nation-state conflicts, to becoming prominent as international influences in their own right. Besides, they are becoming more integrated with other sub-state entities, such as criminal organizations and legitimately chartered corporations, whilst gradually assuming a measure of control and identity with national governments. In the modern age, "the impact of terrorism - that is its ability to terrorize - is not limited to the specific locales or regions where the terrorists strike" (Lavanco, Romano and Milio, 2008).

Using violence as a means of political discourse, terrorist and insurgent organizations have changed the shape of international discourse. The expansion of the Islamic State of Iraq and the Sham (ISIS) or al-Qaeda and its associates, the Taliban, Boko Haram, etc., have been accompanied by reports of gruesome violence that serve as a clear reminder of the enduring influence of terrorism in international politics. From Africa, across the Middle East, 
South Asia, North America and Europe, ISIS, Boko Haram, the Taliban, alQaeda and other jihadi groups are engaged in insurgencies, mobilizing local, regional, and foreign fighters in various theatres of warfare (Global Terrorism Index, 2017).

The terrorist attack of September 11, 2001 (9/11) on the United States was seen as a turning point in the history of political violence. Debates about terrorism have been enthused by the idea that it comes in various forms and that it can be, or has been, transformed. This tendency was significantly intensified by September 11, which some claimed marked the emergence of an entirely new brand of terrorism (Ignatieff, 2004). The incidence of September, 11 changed the global perception about terrorism around the world.

Whilst sophisticated and September 11-style attacks have become more logistically difficult, terrorism is flourishing (Laqueur, 1996; 1999). Terrorist groups have traded sophisticated weapons for ordinary ones; large and relatively expensive operations like September 11 have been replaced by less sophisticated attacks that utilize homemade bombs and readily available guns like the attacks in Paris, Brussels, and before that in 2008 in Mumbai. As terrorism evolved, the smaller-scale attacks of the last decade are rapidly harder to stop and are more terrifying, since anyone skilled at carrying a gun could be a threat and every public space; shopping center, café, or film house or theatre is a probable target.

The global jihadist movement is more widespread and it controls more territory than it did prior to September, 11. It includes the rise of the ISIS organization in Syria, Iraq, and Libya. Many of the associates of the global jihadist movement; those that identify with Al-Qaeda or ISIS, Boko Haram or other organizations, are commonly more absorbed with controlling local territory, and building "statelets" that can be used as cover for global jihadist networks to plan attacks (Miller, 2016).

Between 2002 and the end of 2016, eight of the world's nine regions experienced an increase in terrorist activity, according to the 2017 Global Terrorism Index report produced by the Institute for Economics and Peace. North America was the only region to see a decline. As well as a rise in fatalities, terrorism has also become more widespread (Global Terrorism Index, 2017). The situation has been worse in recent years as terrorist organizations have been proliferated. It is important to note that while they have focused on developing state-like organizations in the Middle East and elsewhere, they have also adopted a strategy for appealing to those who already live in the United States and Europe to launch attacks for them.

The top-five countries in the Global Terrorism Index, 2017: Iraq, Afghanistan, Nigeria, Syria, and Pakistan, had nearly three-quarters of all deaths from terrorism in 2016; all except Iraq saw the number of deaths drop in that same year. Yemen, Somalia, India, Turkey, and Libya rounded out the top 10 countries in the index and ISIS, Boko Haram, Al Qaeda, and the Taliban 
were the four deadliest terrorist groups in 2016, accounting for 59\% of deaths. Furthermore, ISIS was the most potent, with a $50 \%$ increase in deaths from the previous peak in 2015 (Woody, 2017). More countries experienced at least one terrorism-related death in 2016 than in any other year since 2001, with 77 countries affected - 11 more than in 2015 - and $94 \%$ of all terrorism-related deaths happened in the Middle East and North Africa, sub-Saharan Africa, and South Asia (Shtrauchler, 2017).

The past years had more terrorism-related deaths in OECD countries than in any other year since 1988. Europe, in 2016, witnessed the highest number of terrorist deaths in the OECD member countries, which included most of Europe, the US, Australia and Canada, the highest t number since 1988 (Brow, 2017; Shtrauchler, 2017). However, in Europe, there has been a move towards simpler tactics, involving less planning and less people. For instance, the use of trucks has been an especially alarming and effective trend. Evidently, the trend has been in response to the fact that a lot of the complex attacks are easier to foil by the security services. The network of the ISIS in Europe which conducted the Paris and Brussels attacks is an example of ISIS' growing consciousness that despite losing territory in Syria and Iraq, it can mount a real and deadly strategic deterrent-threat to employ against the West.

Military efforts against the Islamic State in Iraq and Syria (ISIS) have intensified and the group has suffered significant losses on the ground. However, though territories controlled by ISIS in Iraq, Libya and Syria have shrunk, as ISIS concedes ground at home, the group lashes out overseas.

Iraqi forces captured the border town of Rawa, the last town under the Islamic State's control. The capture of the town marked the end of the Islamic State's era of territorial rule over a so-called caliphate that it proclaimed in 2014 across vast swathes of Iraq and Syria. Rawa borders Syria, whose army declared victory over the militants after seizing the city of Raqqa, the last substantial town on the border with Iraq (Huffpost, 2017). Hitherto, ISIS controlled a vast expanse of area that spanned both Iraq and Syria. At the height of its occupation, it was said to have controlled a third of Iraq (O'Connor, 2017).

Militant, Islamist groups linked to either Al-Qaeda and ISIS continue to be the main protagonists and will dictate the tempo of global terrorism activity for times to come (Yeo, 2017). The western world is fighting a battle against a new ideology, namely radical Islamism. Interestingly, it is precisely because of the ideology of radical Islam that nations have pursued certain foreign policies, such as going to war in Afghanistan, Iraq, Syria, Yemen and Sudan (International Crisis Group, 2017). As Europe faces a changing and growing range of threats stemming from jihadist groups and individuals, Europeans who are joining ISIS make up one rationale why the rise of terrorism will remain a global threat.

The ability of ISIS to recruit in these countries signifies a number of factors that engendered a conducive environment for such conscription, including: 
a demand for a quasi-revolutionary, anti-establishment discourse and practice, especially among young people who blame their relative deprivation on structural injustice (chiefly Tunisia); a security apparatus in disarray (Libya and Tunisia); the ascent and subsequent reining in of a more political, pragmatic form of Islamism (Tunisia); the presence of pre-existing networks of a jihadist or militant variety (Libya, Tunisia and Morocco); and either lack of regional or international coordination or, worse, regional actors backing rival groups (Libya). (International Crisis Group, 2017; i)

Little progress has been made to address several of these matters, but not in a sustainable manner. Since November 2015, operatives of these terrorist groups in Belgium, France, Germany, and the U.K. have acquired the expertise and materials to assemble suicide bombs without having their plans foiled. There has also been an assortment of plots involving firearms, knives, or some other forms of edged weapon, such as a machete or an axe, and the use of vehicles. The rise in European terrorist attacks coincides with a tactical shift towards simpler and cheaper methods of attack and the threat posed by jihadist militant groups has not diminished (Byman, 2017). Instead, it continues to evolve from structured groups and networks to smaller EU-based groups and solo terrorists or lone actors. These occurrences portend that terrorism will continue to be a problem for the international community. It cannot be eliminated; it can only be degraded and managed to a point that allows everyone to live in relative peace. The lesson here is that terrorism is likely to be part of the cocktail of instability in an increasingly fragmented world.

\section{Conclusion}

\section{Terrorism: Future Developments and Uncertainties}

Terrorism is a globalized phenomenon and like other non-state actors, terrorists are making marks in international politics. The preceding section draws attention to the terrorist networks that evolved after September 11, and how they moved away from an earlier reliance on state patronage to operating as non-state actors. These terrorist networks have taken advantage of porous borders and interconnected international systems such as finance, communications, and transit (Council on Foreign Relations, 2006) to reach every corner of the globe. Some of them concentrate on local or national political dynamics while others pursue global revolution/transformation. Various terrorist groups: Al Qaeda, ISIS and Boko Haram operate with specific goals outside traditional networks. Globally, no state is immune from the scourge of terrorism within its borders. These terrorist groups have moulded our image of violent extremism and the debate on how to address the threat they created. "Their message of intolerance- religious, cultural, and social - 
has had drastic consequences for many regions of the world. Holding territory and using social media for real-time communication of their atrocious crimes, they seek to challenge our shared values of peace, justice and human dignity" (UN Office of Counter Terrorism, 2016, n.d). This global dispersal of their threats compels a comprehensive response that provides solutions at the national, regional, and international levels. A response that tackles both the methods and factors that promote the spread of terrorism.

One domain where the role of non-state actors and individuals is now being underscored is the reaction to terrorism. Following the recognized premise that the phenomenon of terrorism is not new, what is then new is the way in which terrorism has captured the attention of policy makers and publics since September, 11 (Jackson, 2009). Multilateral cooperation on terrorism was encouraged by the renewed energy and urgency that followed the September 11 attacks on the United States and its interests. Subsequent attacks in Europe, Russia, Africa, the Middle East and parts of Asia further advanced this cooperation.

Different approaches and initiatives have been developed, established and created by the international community over the decades to confront the menace of terrorist attacks. Global counterterrorism framework includes sixteen UN conventions and protocols, a vast number of Security Council resolutions, the UN Global Counterterrorism Strategy, and numerous regional instruments. Some regional organizations, such as the European Union (EU), African Union (AU), and the Association of Southeast Asian Nations (ASEAN), have released formal statements stating their shared commitment to counterterrorism (Council for Foreign Relations, 2011). The UN Security Council (UNSC) for instance strengthened the international legal foundation for counterterrorism efforts by issuing numerous binding resolutions. The body also established the Counterterrorism Committee (CTC), and later the CTC Executive Directorate (CTED) to oversee the implementation of the bedrock of counter-terrorism resolutions created after September 11 amongst others (Council for Foreign Relations, 2011).

The United Nations' General Assembly also adopted, by consensus, the Global Counter-Terrorism Strategy on 8 September 2006. "The strategy is a unique global instrument to enhance national, regional and international efforts to counter terrorism" (UN, 2006, n.d).

Through its adoption, all Member States agreed for the first time to "a common strategic and operational approach to fight terrorism" (UN, 2006, n.d). Some practical steps were to be taken, including an assortment of measures "ranging from strengthening state capacity to counter terrorists" threats to better coordinating United Nations system's counter-terrorism activities" (UN, 2006, n.d). The Global Counter-Terrorism Strategy in the form of a resolution and an annexed Plan of Action (A/RES/60/288) composed of the following four pillars have surfaced:

- Addressing the conditions conducive to the spread of terrorism,

- Measures to prevent and combat terrorism, 
- Measures to build states' capacity to prevent and combat terrorism and to strengthen the role of the United Nations system in that regard;

- Measures to ensure respect for human rights for all and the rule of law as the fundamental basis for the fight against terrorism.

The "war on terror" launched by the Bush administration after the 2001 attacks on New York and Washington has however failed to eliminate terrorism. The Al-Qaeda that Osama bin Laden built in the late 1990s does not resemble any of the terrorist organizations that exist today. Terrorist groups are hounded wherever they try to settle. U.S. drones hunt terrorists from Africa to Asia, and raids like the one that led to the death of bin Laden demonstrate that international borders cannot keep terrorists safe (Miller, 2016). The increased difficulty faced by terrorists in finding safe haven where they can live without hiding is one reason these groups have focused on establishing their own statelike organizations in places such as Yemen, Libya, Syria and Iraq: no sensible government would openly shelter these terrorist groups the way the Taliban did in Afghanistan.

None the less, terrorism and violent extremism is on the upsurge. "ISIS's ability to control population centres, blocs of territory, and sanctuaries for fundraising, training terrorists and fighters, and for carrying out its indoctrination efforts made it a ... serious threat" (Cordesman, 2016: 2). Globally, a substantial number has been attracted to ISIS in part because they "perceived it as an empowering, anti-establishment revolutionary group". Confronting this attraction "for a more radical response to the status quo, and pushing it toward non-violent channels" entail "more than security crackdowns, regional and extra-regional intelligence cooperation or regulation of religious discourse (which could well prove counterproductive)" (International Crisis Group, 2017: 32).

The effort to counter the extremist's message seems to be improving, but there is no comparable success in addressing the multifaceted underlying causes that give rise to it. Problems such as civil upheavals, civil war, sectarian and ethnic violence, loss of investment and capital flight, massive refugee and Internally Displaced Persons' problems, fear of Muslims by non-Muslims, and discrimination against Muslims in the West and other areas outside mainly Muslim states alone do not produce some anticipated increase in extremism or terrorism, but are almost certain to make things worse (Cordesman, 2016: 3).

Targeting non-state actors that can easily cross borders and operate in civilian areas thus poses an enormous challenge (Council for Foreign relations, 2011). Also, different techniques for attacking the concerns of terrorism and violent extremism, such as appealing "to the hearts and minds of people...rather than sound facts", highlighting notions of "local resilience and counter-narratives ... as key strategies to target the issue of global radicalisation of youth and the propaganda used by groups such as ISIS", are 
now being advocated globally (Cordesman, 2016: 2). Until these techniques are perfected, the threat both ISIS and other such terrorist groups pose will continue to be a threat indefinitely into the future. Moreover, all of the political, economic, social, and demographics forces that triggered the rise of such extremism and the massive upheaval that have grown worse must be checked (Cordesman, 2016: 3).

Finally, "the war against terrorism, therefore, is not some sort of "clash of civilizations"; instead, it is a clash between civilization and those who would destroy it" (CIA, 2003: 29). Opposition to the supremacy of the state in international system by violent non-state actors has become more rampant and the implication is that those involved in national and international security in the 21 st century will need to formulate and re-strategize more effective and less military propelled ways and means that address the individual's capacity to distinguish between rational and irrational, in order to positively influence the forces that trigger the rise of such extremism in the first place. Until that is achieved, the threats from violent non-state actors will continue to challenge some states as terrorist groups align with others to create a convoluted and perplexing set of geopolitical and organizational networks that will prove difficult to unravel.

\section{References}

Arasli, J. (2011) States vs. Non-State Actors: Asymmetric Conflict of the 21st Century and Challenges to Military Transformation INEGMA Special Report No. 13 Retrieved from http://www.inegma.com/Admin/Content/File-81020131379.pdf.

Ataman, M. (2003) The Impact of Non-State Actors on World Politics: A Challenge to Nation-States. Alternatives, Turkish Journal of International Relations, Vol. 2 No 2 fall.

Aydinli, E. (2013) Assessing violent nonstate actorness in global politics: a framework for analysis. Cambridge Review of International Affairs, 28(3): 424-444, DOI: 10.1080/09557571.2013.819316.

Brow, D. (2017) "Most of the World has Seen an Increase in Terrorism - But Deaths from Terror Attacks Have Decreased" PULSE http:/www.pulse.$\mathrm{ng} / \mathrm{bi} /$ politics/politics-most-of-the-world-has-seen-an-increase-in-terrorism-but-deaths-from-terror-attacks-have-decreased-id7604646.html. Retrieved November 23, 2017.

Byman, D. (2017) Beyond Iraq and Syria: ISIS' ability to conduct attacks abroad https://www.brookings.edu/testimonies/beyond-iraq-and-syria-isisability-to-conduct-attacks-abroad/.

Cerny, P.G. (2010) Rethinking World Politics: A Theory of Transnational Pluralism, Oxford: Oxford University Press.

CIA (2003) National Strategy for Combating Terrorism Retrieved from https://www.cia.gov/news-information/cia-the-war-on-terrorism/Counter_Terrorism_Strategy.pdf. 
Cordesman, A.H. (2016) U.S. Wars in Iraq, Syria, Libya, and Yemen: What Are The Endstates? Center for strategic International Studies, 23 August 2016 Retrieved from https://csis-prod.s3.amazonaws.com/s3fs-public/publication/160823_Defeating_ISIS_IraqSyriaLibyaYemen.pdf.

Council on Foreign Relations (2011) The Global Regime for Terrorism. Issue Brief Report by International Institutions and Global Governance Program. August 31, Retrieved from https://www.cfr.org/report/global-regime-terrorism.

Crenshaw, M. (1985) An organizational approach to the analysis of political terrorism. Orbis 29(3).

Crenshaw, M. (1987). "Theories of terrorism: Instrumental and organizational approaches." The Journal of Strategic Studies, 10(4).

Crenshaw, M. (ed.) 1995 Terrorism in Context. University Park, PA: Pennsylvania State University Press.

Dedeoglu, B. (2003) "Bermuda Triangle: Comparing Official Definitions of Terrorist Activity". Terrorism and Political Violence, 15(3).

EEA Technical report No 4/2011 Global governance - the rise of non-state actors A background report for the SOER 2010 assessment of global megatrends (C) EEA, Copenhagen, Retrieved from file:///C:/Users/PC/-Downloads/Global\%20governance.pdf.

Ertürk, E. (2015) Intergovernmental Organizations (IGOs) and their Roles and Activities in Security, Economy, Health, and Environment. The Journal of International Social Research, Vol. 8, Issue 37.

Ezrow, N. (2017) Global Politics and Violent Non-state Actors. California: SAGE Publications.

Gentry, J.A. (2015) Toward a Theory of Non-State Actors' Intelligence. Intelligence and National Security, Vol. 31, 2016, Issue 4, https://doi.org/10.1080/02684527.2015.1062320.

Goodin, R. (2006) What's Wrong with Terrorism? Cambridge: Polity Press.

Global Terrorism Database Codebook (2017) University of Maryland https://www.start.umd.edu/gtd/downloads/Codebook.pdf.

Global Terrorism Index (2017) New York: Institute for Economics and Peace (IEP) http://economicsandpeace.org/wp-content/uploads/2016/11/GlobalTerrorism-Index-2016.2.pdf.

Held, D. (2016) Global Politics after 9/11: Failed Wars, Political Fragmentation and the Rise of Authoritarianism. London: Global Policy.

Heywood, A. (2011) Global Politics. New York: Palgrave Macmillan.

Hoffman, B. (2006) Inside Terrorism. New York: Columbia University Press.

Huffpost (2017) "Iraqi Forces Take Back Country's Last ISIS-Held Town" https://www.huffingtonpost.com/entry/iraqi-capture-isis-town_us_5a0ecb21e4b0dd63b1a9d010?utm_hp_ref=terrorism Retrieved October 12, 2017.

Ignatieff, M. (2004) The Lesser Evil: Political Ethics in an Age of Terror. Edinburgh: Edinburgh University Press. 
International Crisis Group (2017) How the Islamic State Rose, Fell and Could Rise Again in the Maghreb Crisis Group Middle East and North Africa Report $\mathrm{N}^{\circ} 178,24$ July Retrieved fromhttps://d2071andvip0wj.cloudfront.net/178-how-the-islamic-state-rose_0.pdf.

Jackson, R., M. Smyth, J. Gunning and L. Jarvis (2011) Terrorism: A Critical Introduction. Basingstoke: Palgrave Macmillan.

Jackson, R. (2009) "The Study of Terrorism after 11 September 2001: Problems, Challenges and Future Developments". Political Studies Review, $7(2)$.

Josselin, Daphné, and William Wallace (2001) "Non-state Actors in World Politics: A Framework." In Daphné Josselin and William Wallace (Ed.). New York: Palgrave.

Kegley, C.W. and Wittkopf, E.R. (Eds.) (1995) The Global Agenda: Issues and Perspectives.

Laqueur, W. (1999) The New Terrorism. Oxford: Oxford University Press. (1996) 'Postmodern Terrorism'. Foreign Affairs, 75(5).

Lavanco, G., Floriana Romano and Anna Milio (2008) Terrorism's Fear: Perceived Personal and National Threats. Journal of Psychological and Behavioral Sciences, 2(4), https://waset.org/publications/13994/terrorisms-fear-perceived-personal-and-national-threats Retrieved October 12, 2017.

Long, D.E. (1990) The Anatomy of Terror. New York: Free Press.

Miller, J. (2016) "The Evolution of Terrorism Since 9/11". https://www.rferl.org/a/evolution-of-terrorism-since-911/27782825.html. Retrieved October 12, 2017.

iller, L.H. (1994) Global Order: Values and Power in International Politics. Boulder, CO: Westview Press.

Mulaj, K. (2009) Introduction: Violent Non-State Actors: Exploring their State Relations, Legitimation, and Operationality in Violent Non-State Actors in World Politics. London: Hurst Publishers.

O'Connor, T. (2017) "End of Isis Nears as Forces Supported by U.S. and Russia Close in on Islamic State in Iraq and Syria". http://www.newsweek.com/end-isis-near-forces-support-us-islamic-state-585260, Retrieved October 10, 2017.

Özdamar, Ö. (2008) Theorizing Terrorist Behavior: Major Approaches and Their Characteristics. Defence Against Terrorism Review, 1(2), Fall Retrieved from http://www.coedat.nato.int/publication/datr/volume2/05Theorizing_Terrorist_Behavior_Major_ApproachesandTheir_Characteristi cs.pdf.

Riley, K.J. and Bruce, H. (1995) Domestic Terrorism: A National Assessment of State and Local Preparedness. Santa Monica, CA: RAND.

Shtrauchler, N. (2017) "Global Terrorism Index: Death toll drops globally but rises in Europe". http://www.dw.com/en/global-terrorism-index-death-tolldrops-globally-but-rises-in-europe/a-41385199. Retrieved November 12, 2017. 
UN Office of Counter -Terrorism: Counter-Terrorism Implementation Task Force Retrieved from https://www.un.org/counterterrorism/ctitf/en/planaction-prevent-violent-extremism.

Williams, P. (2008) Violent Non-State Actors and National and International Security. Zurich; International relations and security network.

Yeo, W. (2007) "Four trends in global terrorism threats in 2017. http://www.straitstimes.com/opinion/four-trends-in-global-terrorism-threats-in-2017 Retrieved November 10, 2017. 